\title{
The eternal return of the Praia de Iracema
}

\author{
Ana Paula Luna Sales ${ }^{1}$ \\ 'Instituto Nordeste Cidadania, Fortaleza/CE, Brasil
}

\begin{abstract}
The purpose of this article is to trace the paths of "destruction" of the Praia de Iracema, in Fortaleza, which have been documented from the nineteenth to the twenty-first century. It is inspired on my own ethnographic study conducted between 2015 and 2017 with transnational missionary projects that confront "sexual crimes" in Fortaleza. The article examines the dual process of selective use of scientific epistemology and the brutal crushing of other epistemologies in their relation with the recurring endings of the Praia de Iracema. Crossing knowledge from anthropology, geology, history, politics, and physics, I sought to perceive how the entanglements of agencies between humans and non-humans generate the eternal return of the Praia de Iracema, bringing to light the irrational rationalities of humanist times.
\end{abstract}

Key words: ruins, "sexual crimes", coastal alterations, scientific rationality. 


\section{O eterno retorno da Praia de Iracema}

\section{Resumo}

Este artigo tem a proposta de rastrear os caminhos das "destruições" da Praia de Iracema, em Fortaleza, documentados desde o início do século XX. Partindo de minha própria pesquisa etnográfica, realizada entre 2015 e 2017 com projetos missionários transnacionais de enfrentamento a "crimes sexuais" em Fortaleza, atento para o duplo processo de uso seletivo da epistemologia científica e de esmagamento brutal de epistemologias outras em sua relação com os recorrentes fins da Praia de Iracema. Cruzando saberes da antropologia, geologia, história, política e física, intento perceber como os emaranhados de agências entre humanos e não humanos geram o eterno retorno da Praia de Iracema, trazendo à tona as racionalidades irracionais de tempos humanistas.

Palavras-chave: ruínas, "crimes sexuais”, alterações costeiras, racionalismo científico. 


\title{
The eternal return of the Praia de Iracema
}

\author{
Ana Paula Luna Sales
}

They also learned vanity from the sea; isn't the sea the peacock of peacocks?

(Nietzsche, [1883]2008, p. 101)

While I write this article, visions and noises from the latest intervention on the coast of Fortaleza churn my thinking. The drag-ship that is once again placing sand on the Praia de Iracema beach has shown its predatory face, on morning walks I note that waves without sediments are breaking with much greater strength.

I learned about the sociotechnical processes of "destruction" of the Praia de Iracema a few years ago when I studied them to analyze the transformations in international tourism on the Praia de Iracema beach, a research field in my doctoral thesis Da violência ao amor: economias sexuais entre "crimes" e "resgates" em Fortaleza, [From violence to love: sexual economies between "crimes" and "rescues" in Fortaleza], supervised by Adriana Piscitelli, supported by CAPES and Fapesp (Processo 2015/13332-7) and defended in the Graduate Program in the Social Sciences at Unicamp, in 2018. My main argument proposed that on the margins of Fortaleza, the policies to confront "sexual crimes" were undone by and mixed with the dynamics of sexual economies.

As a territory of these dynamics, the various histories of "destruction" of the Praia de Iracema, were analyzed considering how human and non-human agencies combined to generate unexpected effects. At first, I perceived ignorance and neglect in this web of agencies. However, considering the productive character of the government interventions, which had been observed in the policies to confront "sexual crimes", and inspired by Friedrich Nietzsche ([1883]2008), I argue here that the destroyed Praia de Iracema is not a past that "it was [like that]", but a present and future that "thus [we] willed it".

I do not usually write in the first person plural, but in this case, I cannot write any other way. Because even considering my love for the beach, to see it being destroyed once again and understanding the reasons, I am not able to do anything that can stop the destruction, although I have so much to lose. Imagine the administrators, developers, real estate speculators and hotel owners who believe they have so much to gain! Everyone will lose.

In the efforts to confront "sexual crimes" and in the alterations of the Fortaleza coastline, the same discursive strategies operate in which the form of production of knowledge that guides the academic community is forgotten or discarded. Without considering ethics in the presentation of results or critical analysis of data, alternative discourses about socio-technical dynamics have disturbed researchers from various fields (Mann, 2012).

In the theme of confrontation of "sexual crimes" the Pesquisa sobre Tráfico de Mulheres, Crianças e Adolescentes [Study of Trafficking of Women, Children and Adolescents] - Pestraf (Leal e Leal, 2002) is a classic case in which the results, although invalidated due to grave methodological problems, do not cease to produce policies (Blanchette e Silva, 2012; Piscitelli, 2013).

The Fortaleza coast, in turn, has been the object of various studies, in which both the adverse oceanographic effects of port construction and structures to prevent erosion (Morais, 1972; Pitombeira, 1976; Ximenes Neto, Morais e Pinheiro, 2018) as well as the social harm are widely documented (Benevides, 2003; Bezerra, 2008). The rigidity of disciplinary frontiers, however, often causes an absence of dialog between these productions and a lack of knowledge about the magnitude of the effects unleashed in previous interventions. 
The purpose of this article is to trace the narratives of progress in the Praia de Iracema through their dual process of selective use of scientific epistemology and brutal crushing of other epistemologies, based on experience. To do so, I use as reference interventions in various moments from the nineteenth to the twentyfirst century, focusing on the "intraction" (Barad, 2007) between humans and non-humans.

Through an ethnography realized between 2015 and 2017, accompanying missionary projects to confront "sexual crimes" in Fortaleza, I found that the most recent discourse about the "destruction" of the Praia de Iracema, relating to meetings between "gringos" [men] and "nativas" [women] that were classified as "programs" [tricks] at the end of the decade of 2000, involved a re-editing of an older narrative about love, sex, money, progress and decaying buildings that marked the history of the neighborhood.

Among the different stories of a search for the redemption of a feminized, racialized and sexualized Praia de Iracema, it is possible to distinguish tensions of class and race that permeate both the high investments made as gift (or dowry?) to her [the beach] and how they, once and again, lead to her ruin.

I organize the text in five topics. In the first I discuss the processes of feminization, racialization and sexualization of the Praia de Iracema in the early twentieth century. I then analyze how this femininity was inscribed in the tensions between local and global in the imaginary of the local middle classes through a government project at the end of this century. This leads to the turn of the twenty-first century, when femininities informed by feminist agendas that defended the right to pleasure and gender equality challenged the narrative of romance on the beach. In the fourth topic, I return to stories whose effects haunt the beach, even when not told. I then analyze how the practice of confrontation of "sexual crimes" reproduces the dynamics of the sexual economies of the Praia de Iracema in a context of crisis. In conclusion, I note how the eternal return of the narrative of progress illuminates the entanglement between ontologies and epistemologies upon which are constructed inequalities in the city.

\section{Virgin-beach-woman}

The chronology of the Praia de Iracema usually begins in the 1920s, when the beach was removed from its "bucolic" state considered "original" and began to be frequented by the city's elites. In this period some "palacetes" [mansions] were built that underwrote the "beauty of the place" and its availability for the installation of "progress" (Benevides, 2003).

The elegance demanded of the Praia de Iracema by the "traditional families" required a series of transformations, because its beauty was perceived to be simultaneously natural and as an object of various technological interventions (Preciado, 2008). The name Praia do Peixe, [Fish Beach] used until then, had to be changed, because it was considered "inappropriate and vulgar" for the newly planned uses. When the beach became "de Iracema", it is feminized and "described with characteristics of romantic aesthetic standards, similar to the Indian woman idealized by novelist [José de Alencar] in 1865" (Bezerra, 2008, p. 19).

The neighborhood, which was "denuded so it could receive and enchant" (Bezerra, 2008, p. 19) also earned the nickname of the Praia dos Amores [Love Beach] (Barreira, 2007). The "passionate" beauty of the beach-woman was used as a strategy of seduction aimed at a masculinized "progress" that came "from the outside", through ships that docked at its port (Benevides, 2003, p. 21). The lack of safe conditions for maritime disembarkation, an issue recurrently mentioned in reports from foreigners about the capital during the nineteenth century (Jucá, 2003), hindered this encounter.

From the first piers, built after 1807, until the inauguration of the Porto do Mucuripe in 1945, the accumulation of sand in the substrate did not fail to bury the local dream. Maia, Jimenez, Serra and Morais (1998) noted that, in the period of the construction of the Port of Mucuripe, data from soundings already indicated that the zone running from the Bay of Mucuripe to the Praia da Leste had a large quantity of sediment and a current that 
flowed from east to west along the coast. Cause and effects, however, did not appear to have been linked not even in actual experience, or in the science of the ports.

Thus, the various port installations led to a series of changes along the coast that range from coastal siltation at the Ponte da Alfândega [Customs Bridge], which was inaugurated in 1906 and restored in 1924, when it became known as the Ponte Metálica [Metal Bridge] (Rodrigues, 2013, p. 20) to the effects of erosion, and following siltation, related to the Porto do Mucuripe (Maia, Jimenez, et al., 1998).

The Ponte dos Ingleses [English Bridge] was particularly important in the web of consumption, colonialstyle power relations, materials and waves in the production of urban decay. Its construction began in the 1920s, by an English company, which led to the name, but was never completed (Bezerra, 2008).

The installation of "palacetes" and clubs in the village at the Praia de Iracema combined with the successive siltation of the coast, put an end to the project for a port at the location. The "chic" beach would be reserved to the pleasures of leisure, far from the inconveniences of the practical world, like a Victorian lady (Millet, 1970).

In 1930, the bay of Mucuripe was chosen as a location for the new port, which came to be a priority. During the drought of 1932, part of the population removed from the country was employed in the construction, which was financed with federal drought-relief funds (Rios, 2014). Geologists interested in the contingent effects of the port on the Fortaleza coast, such as Morais (1972) and Pitombeira (1976), indicated, however, that its construction only began in 1939 and was completed in 1945.

During this interval, World War II erupted and Fortaleza became an official US military base. With its command post far from the city center (and located where is now the neighborhood Planalto Pici), the Praia de Iracema became an exclusive club for the relaxation and fun of the soldiers.

The Vila Morena mansion (now known as Estoril), built by a wealthy local developer, became the "Americans Club", the site of parties and transnational encounters that during the war period created a new scenery at the Praia de Iracema:

More tranquility because of the little movement at the port, the monotony was broken by the coming and goings of jeeps to transport local authorities and foreign officers, the Praia de Iracema experienced new products that arrived not through the Ponte dos Ingleses - Metálica, as it is better known [the author confuses two different bridges] - but in the large American war jeeps. There were chiclets, cigarette packs, whisky, canned goods and mainly Coca-Cola (Benevides, 2003, p. 21).

According to the author, "the Americans took full advantage of their tropical paradise" and "once in a while transformed the bucolic beach and its slow pace of fishermen home from sea, with large and tumultuous parties". The parties were restricted to the Americans and some Brazilian guests. At these parties, the attention of the GIs" was disputed among the "moçoilas" [young girls] from families from the location and the "immaculate daughters of the Cearense families" (2003, p. 22).

The meanings of the relations between the young "native" women, both rich and poor, and the American officers were debated. If, on one hand, the proximity with the Americans their "culture" and their "goods" signaled the realization of the "dream of progress", on the other hand, Benevides commented that "arguments and fights" erupted when "a father or son discovered that one of the daughters had been invited to grace the parties with her presence" (2003, p. 23).

With the end of the war and the departure of the Americans, the women and the beach that hosted the bearers of progress soon had their "enchantment" metamorphized into "decadence". The proximity with the Americans, their "culture" and their "goods" that were once valued, later generated anxiety because of the transgression of norms of gender and sexuality. The name "coca-colas" was given to these youth, transforming

$1 \quad$ Acronym used for US soldiers. 
them from consumers of progress into the "product" of "degeneration" (McClintock, 2010). In the first decade of 2000, "coca-colas" was still a synonym for prostitutes (Bezerra, 2008). Meanwhile, the beach was ravished by a violent process of erosion and flooding provoked by the advance of the sea over loves, large homes and dreams of development (Maia, Jimenez, et al., 1998).

\section{The beach between the local and the global}

The period that followed the flooding was described in the local literature as the "stopped" time. In the 1960s, Estoril was considered a place for the "intellectualized sectors of the city" (Bezerra, 2008, p. 70). The "palacetes" still standing contrasted with the precariousness of the poor houses and urban infrastructure in the neighborhood, something that it had in common with so many others in the city, and which in that context guaranteed it, once again, the adjective "bucolic".

The narrow unpaved streets exposed an architecture of various styles denoting the influence of previous epochs, shacks of mud and brick, glued one to another, shared space with the large houses, remainders from the $1920 \mathrm{~s}$ and 1930s, of an ephemeral summer elite (Benevides, 2003, p. 25).

Artists and other people who lived in the neighborhood joined together in associations in the 1980 s to demand, preservation of the neighborhood, and "recuperation and improvement of the sanitation system, street cleaning and sewerage, transit and lighting” (2003, p. 21).

This period was also marked by the perception of the "picturesque" and "bohemian" character of the neighborhood and its tourist potential. In an attempt to "modernize" the image of Fortaleza, since the mid 1980 s state and municipal governments made the Praia de Iracema a "showcase" for their administrative policies (Bezerra, 2008, p. 60).

I remember skates and soap bubbles at sunset that enchanted me when the pedestrian mall of the Praia de Iracema was inaugurated in 1994, and the Ponte dos Ingleses, in 1995, and which were briefly part of my circuit of childhood outings. This was considered the first government intervention in the Praia de Iracema aimed at exploiting its tourist potential.

But it is important to remember that the state also acts by not acting. The failure to declare the neighborhood protected heritage as had been requested since 1981; the issue of licenses to commerce "without any restrictions" during the 1980s; and the approval of three construction projects with tall buildings in an area that was designated for preservation, led to changes that were often read as being initiated by the "state", but that involved an intricate web of subjects and institutions.

Among agents of "real estate speculation" and owners of bars stands out the action of the Portuguese native Júlio Trindade and in his large nightclub, the Pirata. Founded in late 1986, "Pirata contributed to the fast social and spatial transformations of the Praia de Iracema" (Bezerra, 2008, p. 83). The disputes about the meanings of this change were associated to the idea of "progress" or "decadence".

Once consolidated as the main tourist destination of Fortaleza, the Praia de Iracema was populated by new bars and restaurants that received the local middle classes, Brazilian tourists, and in lower number, international tourists. This configuration was already causing problems in 1995, when a conflict arose because of the "lack of harmony between bars and residences" (2008, p. 89).

The new visitors who "tore through the old and peaceful streets of the neighborhood in cars with speakers at high volume" terminated, once again, the "bucolic" character of the neighborhood and "silenced the poetry and art" (Benevides, 2003, p. 51). The description appears to refer to the middle-class residents of Fortaleza and "questionable tastes" that began to visit the neighborhood. In 1989, the S.O.S Iracema campaign was launched: 
to mobilize society, convoking action in defense of human rights and citizenship, and given the complexity of the situation caused by the large number of bars and nightclubs, in a strident struggle to conquer a high-tech youth. (2003, p. 52)

It is important to note the use of the notion of human rights in the preservation of a certain lifestyle, marked by rhythms, tastes and specific ethical subjects, who felt "invaded" by other residents of the city. What is unique about this case is that the invaders are middle class clients of "top of the line bars". Benevides noted that "the defense of the territory is combined with the defense of quality of life" (2003, p. 58), which can be understood to refer to a specific lifestyle. In the dispute over territory, references to indigenous residents were used that depicted the so-called "high tech bohemia" of the city to be "foreign invaders".

When Benevides wrote her thesis, the "problem" of the "gringos" was still incipient. The image of the "foreign invader" would in many ways be triggered and materialized in coming years. However, her text includes a fundamental element of the production of tourism at the Praia de Iracema that allows foreseeing the dispute that would arise in the neighborhood in coming years: the government production of the "aesthetization of culture".

Analyzing the cultural development plans implemented by the state government in the process of "modernization of the state", Benevides argued that the "aesthetization of culture" was operated through local middle classes, who were entrusted to articulate culture as a commodity.

In other words, it involves reinventing a culture, endowing it with meanings linked to the market, so that new sensibilities, which emerge from interaction between society and cultural goods, can be established, creating the environment needed for selling the experience as commodity (2003, p. 213).

The "aesthetization of culture" at the Praia de Iracema as a state production to adapt the neighborhood to the transnational tourist market should be considered within the dynamics of the transnational sexual economies that were established in the city since the decade of 2000.

\section{Exotic-beach-woman}

In field research conducted in 2005 about representations of the Praia de Iracema, Bezerra concentrated the analysis on disputes over the uses of the neighborhood. In this scenario, the presence of "native girls and foreign [male] tourists" in nightclubs on Potiguaras and Tremembés streets was seen as a cause of the (latest) degradation of the Praia de Iracema.

Beyond the representation of these bars as a "place for prostitutes and gringos" (2008, p. 107), the presence of people living in the streets, classified as "hippies" or "boys sniffing glue", and of people considered "dealers", in the middle of the decade of 2000 they also promoted the image of a "mixture" to associate it with other infrastructure in the neighborhood such as the Ponte dos Ingleses and the pedestrian mall. About the circulation of "poor youth in public spaces" accompanied by "gringos" Bezerra notes:

It is worth emphasizing that, in this context, social class is related with skin color, because some reports classify those who accompany foreign men as "moreninhas" [brown girls], "negrinhas" [black girls] and even, "macacas" [little monkeys]. Thus, the link between these different people in racial, cultural and economic terms came to be associated to prostitution (2008, p. 192).

However, her analysis of issues of race and color ends there. Much of the academic production about the Praia de Iracema recognizes the disputes over the articulation of categories of gender, race, class, age, sexuality and nationality, but do not promote an intersectional analysis that allows recognizing the differences and inequalities at play. 
Adriana Piscitelli (1996) has called attention to the need to analyze the effects of intersectionality on the production of inequalities in contexts considered to involve "sexual tourism" since the mid 199os. In texts based on studies about the circuit of international tourism in Fortaleza in the early years of the decade of 2000 , Piscitelli described how the articulation of categories of difference operated not only in the possibilities and limits of agency of subjects, but also in the production of territories in the city.

Situated in a complex meshwork that combined national inequalities manifest in terms of sexuality and color, local "machismo" and "rigid racial and class barriers", "native" young women recognize in relations with foreign travelers a form of escaping a network that they perceive as something that imprisoned them (Piscitelli, 2004, p. 303).

This does not involve forms of open resistance to inequalities, but of the agencying of the complicated network that combined colonial past, dreams of modernity and government strategies for cultural aesthetization of the Praia de Iracema. As Piscitelli (2013) synthesized, these women sought to avoid the local constraints that limited their ideas of "liberty", triggering other inequalities instituted by transnational relations in sexual economies in Fortaleza.

In the first half of the decade of 2000, these women had access to substantial quantities of money and various love affairs in a context of fluid sexual-economic exchanges with the gringos (Piscitelli, no prelo). In the ethnographic research that I conducted in the neighborhood, I met Chris, a Dutch nightclub owner, who I encountered in the streets of the neighborhood at various times during my study. He expressed longing for a time when the beach was just a "party":

[It was] a party every night until 6 or 8 in the morning on the beach. It was much better than Ibiza, it was a constant party. What the gang found in Ibiza, Fortaleza had. The people who live here didn't know, they didn't think of this, it was cool here, but then we had 2 flights from Holland each week, 4 from Italy, Germany, Switzerland, everyone came here and the public was much younger, the group that came here from college, the group that came to spend money. After the crazy city government said that they would crack down on the sexual tourism by Europeans... the sex trade, Fortaleza, what happened? When you go somewhere where you see a lot of sexual tourism, its normal to do what? You stop going! What public will you attract? The sexual tourists who didn't [even] know it existed. Again, after the World Cup [2014] they cracked down on sexual tourism that the majority didn't know existed here. The good public went away and the sex tourists came. ${ }^{2}$

From Chris' perspective, at the time when people in the neighborhood began to denounce "sexual tourism" and demand the "moralization" of the Praia de Iracema, what was going on was a big party where European youth came to have fun, spend money and find love with "native" young girls. This was Chris's own experience, a man of about 40, bald, with blue eyes, a bit overweight, who was married to a "morena" [brown-skinned] Brazilian.

Cases like the one of a Dutch man who was charged with sexual exploitation of children and adolescents, which received widespread attention in the European media, were an exception at the time. Chris, believed that it would have been better to "keep quiet and solve the problem", because the charges "totally ruined Fortaleza" and, in combination with the tsunami that devastated Thailand in late 2004, steered the "old men", "sexual tourists", to Fortaleza. They had "scared off" the "good public" and, according to Chris's calculation, since then, $95 \%$ of the foreigners who travel to Fortaleza were looking for "hookers".

2 Interview, 6 February 2014. 
For Chris, these "old" men were only interested in alcohol, drugs and prostitution. By becoming the owners of bars and nightclubs at the Praia de Iracema, they had imposed these dynamics on the neighborhood that was "sold cheaply" to them by the Brazilian owners. In 2008, when Chris mounted his first nightclub, he remembers that there were only rundown buildings on Rua Tabajaras. "The most beautiful place in Fortaleza, I'm sorry, but I don't understand how you were able to abandon this place". 3

The new "destruction" of the Praia de Iracema is difficult to understand because it presumes knowledge of the history of articulation between inequalities of race and class in a post-colonial context in Fortaleza. A knowledge that has been systematically obliterated in official and academic local discourses.

In the local academic production about "sexual crimes", the authors repeatedly affirm the "vulnerability" of people in relation to class: "low income and broken families" (Feitoza, 2010, p. 44); "poor girls are recruited by criminals to be sexually exploited" (Costa, 2008, p. 187); "the understanding about human trafficking for purposes of sexual exploitation (...) should be based on this class dichotomy" (Sousa, 2013, p. 147).

The centrality of class in the analysis of the "sexual crimes" in Fortaleza condenses local knowledge into scientific discourses. Representing the social hierarchies in terms of class, this production is based on the ideas of "constructed" differences (in opposition to those thought of as "natural") and for this reason, can be overcome.

To think of inequalities in terms of class allows imagining mobility based on different elements and through multiple strategies. This imaginary of social mobility through class ascension - nurtured by people who occupy different positions in the social hierarchies of Fortaleza, rarely extended to local relations - became closer with the insertion of the "gringos" in the sexual economies of the city.

These men, from Europe and the United States, associated the "morena" color of the women to positive styles of femininity, considered to be traditional, and associated to sensuality, affection and "simplicity". In this interplay of "exotization" and "inferiorization", class differences were not always legible to the "gringos", which produced a "mixture" in the transnational sexual economies (Piscitelli, 1996; 2005).

This situation, where class inequalities among "native" women lost importance, did not produce, however, equality among them. Racial and chromatic differences, central to the production of desire of the "gringos" in exotic contexts, came to be explicitly triggered in the production of local inequalities (Piscitelli, 1996; 2004; 2007). Thus, the definition of "class" in the local academic production as a fundamental category in the hierarchies in Fortaleza, was increasingly informed by empiric processes of racialization and sexualization, making it a nearly "natural" attribute.

When the social hierarchies of racialized class were blurred by the colonizing gaze of the "gringos" and the racialization was felt as a process of generalized inferiorization by Fortaleza residents, it was "enclosed" in the Praia de Iracema that, separated from the legitimate city, was transformed into a territory of "whores" and "gringos" and, thus, once again "ruined".

\section{The ghosts of the beach}

There is a vast local academic production that examines the Praia de Iracema. Most of the work analyzes the neighborhood through its buildings and the public policies that affect them, while few are about the people who live in them. The ghosts that inhabit the Praia de Iracema, however, are found in other studies that, by passing along the beach, challenge the analyses about the public policies for tourism and gentrification. They reveal the interplay of shadow and light that permeate the complex web of discourses about the beach.

3 Interview, 6 February 2014. 
José Hilário Ferreira Sobrinho (2011), upon describing the movement of the jangadeiros ${ }^{4}$ against carrying enslaved people at the Praia de Iracema, notes that most of the people victimized by the inter-provincial slave trade from Ceará headed mainly to southeastern Brazil were captured or born in the region.

According to Mariana Assunção, this was due to a process of "creolization" that began long before the prohibition of the international slave trade in 1850 (2002, p. 41). The post-mortem inventories analyzed by Assunção distinguish those captured or born in Brazil from those coming from Africa by the racial, ethnic and chromatic classifications imputed to them. While the captives from Africa, especially south-central Africa, were classified as "Angolas", "Cabinda" and "Caçange", according to the author, "Crioulo" was a broad category, that encompassed an extensive chromatic spectrum of slaves born in Brazil: "pardos" [browns], "cabras" [half-breed], "mulatos", "pretos" [blacks] and "caboclos".

The multiplicity of denominations represented in the chart [prepared by the author] reveals a high percentage of mestizos among the captives of Ceará. It is probable that many of them were natives to the region or from neighboring provinces (2002, p. 46).

According to Ferreira Sobrinho, it was precisely the fact that the enslaved people were native to Ceará that was manifested in the interprovincial slave trade and which stimulated, in periods of drought, its most vile character. The interprovincial trafficking of captives caused people, who for many generations had lived in a single place, to experience the uprooting similarly to how their ancestors were taken from Africa. In the words of the author:

To be sold through interprovincial trafficking represented immeasurable harm to the captive. It meant losing the conquests acquired, the uprooting that would provoke a rupture of a precious good: a break with affective-family ties or those of friendship (2011, p. 45).

In a general population of people "of color", according to the censuses analyzed by Ferreira Sobrinho, the violence instituted by interprovincial traffic victimized, in addition to the captives, Afro-descendants who were born free, or those who at some point had gained freedom. It was also the confusion of the limits between the captive population and the poor and racialized free population that would allow, in periods of drought, captives to escape sale and capture, along with others forced to migrate from the region, known as "retirantes".

Since this period, the production of new social limits appears as one of the main objectives of the local elites. The ambivalence of "color" that opened space to violations, but also agency, was progressively supplanted by the opposition between "liberty" and "slavery". The solution found by many "masters" was then to rid themselves of the captive contingent through their sale (2011, p. 182).

The discourses of the abolitionist legislators analyzed by Ferreira Sobrinho, indicate that the "anticivilizatory" and "anti-Christian" institution of slavery should end in Ceará, as in the entire "civilized" world, but little was discussed about the destiny of the enslaved people. Paradoxically, the end of slavery in Ceará could be conciliated with the sale of captives to other states.

Far from the legislative chambers and other spaces of power, the interprovincial traffic was actively fought by many of those who were submitted to it through revolts, escapes and judicial processes. The movement of the jangadeiros against accepting the boarding of the captives on their rugged boats was articulated in continuity with these resistances, which were partially assimilated by elitist abolitionist movements, and was recognized as the first registered social movement of the Praia de Iracema:

$4 \quad$ Artisanal sailors traditional to the region. 
On the morning of 27 January 1881, on the Praia do Peixe (today the Praia de Iracema), in Fortaleza, some traders, with their slaves, awaited, as customary, the jangadeiros, to transport 14 captives to the steamship "Pará", found on the route Norte-Rio de Janeiro-Norte. The boat was anchored, awaiting the slaves for another journey South, with a considerable number of slaves "to deliver".

Something different would occur on that day: the jangadeiros were very late for the service. Upon looking for information about the delay, those responsible for the loading were surprised by the news that the men of the sea refused to put the slaves on the jangada. [...]

The news of this action of the jangadeiros spread rapidly, and people went to the beach to watch from up close the unprecedented scene of a group of poor fishermen who decided to confront representatives of elite merchants linked to interprovincial trafficking, by refusing to carry slaves on their jangadas. Even more significantly, the movement was led by blacks, pardos [browns] and mulatos (2011, p. 263).

The emphasis in the epithet Dragão do Mar [Dragon of the Sea], conferred by the Sociedade Cearense Libertadora [Ceará Abolitionist Society] to Francisco José do Nascimento, better known as Chico da Matilde, to represent the "abolitionists of the beach", hides the action of the "network of solidarity involving free blacks (...) under the leadership of two men of color and of the sea" who made abolitionism in Ceará visible (2011, p. 314).

The erasure of this scene from the history of the Praia de Iracema is noted in the bibliography that sees the Praia de Iracema as being born from the Praia do Peixe (Benevides, 2003; Bezerra, 2008), forgetting the jangadeiros in their work in shipping at that port, ravished by "violent waves" (Jucá, 2003) and silted by the deposit of sediments, as well as their struggle against the interprovincial trafficking.

The aesthetization of culture that the Praia de Iracema experienced in the late twentieth century erased differences between the actions of jangadeiros, the Ceará Abolitionist Society and "senhores" [masters] of slaves that, for various reasons, led to the abolition of slavery in Ceará in 1884, four years earlier than the rest of Brazil. This is best seen in the manufacturing of the nearly mythic figure of the Dragon of the Sea (Ferreira Sobrinho, 2011). A confusion of reasons, names and places allow simultaneously considering the state to be a context free of "traditions" (Benevides, 2003) while also inventing the notion of a homogeneous "brave" and "hospitable" people. The confusion between the Ponte Metálica and the Ponte dos Ingleses, more than an error, should be read in its productive aspect. The ruins of both attest to the failure of progress in the city.

In 1945, the inauguration of the Port of Mucuripe coincided with the departure of the "American soldiers". The beach suffered the immediate effects of the port, which proved to be a failure once again. Its seawall soon filled up with sand, its disembarkation site was not protected from the waves that came from the east; and other beaches, to the west, suffered strong erosion, with the Praia de Iracema the most affected (losing $130 \mathrm{~m}$ ). Years later, the construction of a new seawall and expansion of the first, to contain the waves from the east, resulted in even more erosion of the Praia de Iracema (another $56 \mathrm{~m}$ ). Meanwhile, the jetties built to contain the beach refracted the effects to beaches farther west (Maia, Jimenez, et al., 1998).

As Jáder Onofre de Morais noted, the idea of a Port at Mucuripe was executed without conducting studies of the oceanographic and sedimentological conditions of the adjacent area (Morais, 1972), or without considering the existing bathymetry studies (Ximenes Neto, Morais e Pinheiro, 2018). This caused the effects on the beach and the port itself to be completely unexpected:

The first consequences of the non-realization of these studies was felt soon after the construction of the port: a Northwest current approximately parallel to the Praia do Futuro, loaded with suspended sediments [sand], found the seawall of the port to be an obstacle to its normal course, in direction of the continental shelf. The defraction of the waves on the dike, which generated a whirlpool effect, caused the suspended material to be deposited along the dike, forming a small beach [Praia Mansa] and making the immediately adjacent zone shallower. 
After this sedimentation, the current, without suspended material and with increased erosive strength, was reflected in direction of the Praia de Iracema, resulting in its destruction (MORAIS, 1972, p. 141).

There was no conscientious choice. No contract, in which something (the Praia de Iracema) was given up to gain something else (the Porto do Mucuripe). There was only an experiment, which had a terribly equivocal result. The Porto do Mucuripe proved to be functionally unsuitable and caused flooding of the Praia de Iracema.

Roselane Bezerra, in her thesis that analyzed the pendular nature between representations of "goodbye" and "renovation" at the Praia de Iracema, noted that the changes in uses and representations of that space were the main consequences of material destruction of the beach and of the buildings around it provoked by erosion. The author affirmed:

This representation of the beach was immortalized in a song by singer and composer Luiz Assumpção, entitled "Adeus Praia de Iracema", which was popular in the carnival of 1954. The song announces a sense of loss for the city, by means of the words adeus, saudades, passou and fracasso [goodbye, longing, passed and failure]. The song also reproduces the visibility of uses in the neighborhood associated to the idyllic, with the description of passionate couples who, between kisses and hugs, exchange oaths of love (2008, p. 40-41, emphasis by the author).

Bezerra points to the productive character of the discourses about the "destruction" in the subsequent policies to which the beach was submit: "I understand the melancholic tone that describes this end as a 'founding myth' of an entire discourse of degradation of the Praia de Iracema" (2008, p. 41).

Nevertheless, it is also important to note the opposing discursive practices, represented by the same "bohemians" who left the beach, but continued to frequent the restaurant located in the Estoril building after the departure of the "Americans". Meanwhile, the stones placed to contain the advance of the sea formed a "small pool", which "soon became a place for meeting and leisure for the entire community" (Benevides, 2003, p. 26). And even Luiz Assumpção, who had said "goodbye" to the beach, had his name immortalized on one of its facilities.

Moreover, Luiz Assumpção did not sing alone. Participants in the group of "traditional bohemians" continued to live in and praise the neighborhood that, after all, contrary to the narrative, continued to exist in people, homes and parties. I met Roberto, one of these bohemians, who was older than 10o. His son, Robertinho, proudly showed me a book in which he appeared, with his friends and their musical instruments, as part of the history of the Praia de Iracema which had reached the "end".

The endings of the Praia de Iracema may be better described as endings of progress (Tsing, 2015). However, without ever abandoning it in the imagination, we, Fortalezans, live its eternal return. The ghost of the Praia de Iracema is progress: "Not only the reason of millennia - their madness too breaks out in us. It is dangerous to be an heir" (Nietzsche, [1883]2008, p. 58).

\section{Praia de Iracema, eternal love?}

The first material deterioration of the beach in the twenty-first century was generated by the desertion of the middle classes, in 2005, which combined with the economic crisis in Europe in 2008, to once again produce its "destruction". After 2012, this "destruction" was felt by the sex workers, when the "gringo" tourists disappeared from the neighborhood.

Since then, the precariousness of sex work in the neighborhood has increased. In 2016, when I conducted a field study, not even the professionalization of the "programas" [tricks] resulted in sufficient earnings for most of the women to maintain their desired standard of living. They also sought to diversify their sources of income, working as masseuses, nurse's aides, hairstylists, lathe operators, sales promoters in supermarkets, eyebrow 
designers, and in other professions. Even women who had a home, car and practices of luxury consumption thanks to earnings from the clubs at the Praia de Iracema sought other activities given the uncertain future.

Chris had a bar and a large nightclub where parties were held for a young public in the city who "did not have a lot of money", different from the other nightclubs owned by foreigners in the neighborhood. He dreamed of the day when the Praia de Iracema would return to what it was, without the "old gringos", who he believes ruined the beach. He established a hierarchy of masculinities to distance himself from the "sexual tourists", something observed in other contexts of international tourism, as in Bangkok (Roux, 2011) and Rio de Janeiro (Blanchette, 2011).

In Copacabana, in Rio de Janeiro, Thaddeus Blanchette (2011) perceived hierarchies among foreign masculinities related to the abandonment of the status of tourist and the adoption of behavior considered to be "more Brazilian". According to Blanchette, the procedural and nearly inevitable character of this transformation would be intimately related to the racialization of Brazil. The "cultural training" perceived by the "gringos" in the racialized and sexualized Brazilian women, regardless of their relation with prostitution, would also have a counterpart in the foreign masculinities.

The category "gringo-cafuçu" was coined by sex workers of the Praia de Iracema to designate types of disdained masculinities found among the foreign men. It synthesizes, through a contradiction, aestheticmoral evaluations of masculinities at the Praia de Iracema today. The positivity of whiteness associated to the "gringos" is neutralized by the negative racial category cafuçu5. The moral content associated to this destabilizes the aesthetic positivity of "gringo" whiteness. By hyphenating masculinities situated at opposite points of the hierarchies in the sexual economies, the sex workers do not abolish the limits, but multiply them.

To escape this classification, Chris evokes ontological differences between "gringos": the "good public" does not mix with the "sexual tourists". However, given these dichotomic moralities, his own position becomes ambivalent. Chris likes to "speak with everyone". More than once I found him in the bars of foreigners at the Praia de Iracema. His wife disapproves of this: "when she knows that I go to the club [she demands] that I stay home: 'what are you going to do there? You're married!".

What would be the difference between Chris and the "old gringos" from the perspective of the sex workers? Probably none. Chris' discourse, who described himself as "machista", about the women who circulated at the Praia de Iracema, made his ethical position closer to that assumed by other "gringos". He said that until 2005, any women would go to the Praia de Iracema to go out with the "gringos", but since 2008 he believed that all the women found in the region were " $100 \%$ whores".

What I think about this place, I think its shit, why? Everyone is lying; the only thing that a whore wants is money. She does not want to know about the man, she wants to know about her life. And the men here are dumb, if they fall in love so quickly for the woman and the women here...imagine if you have 10 boyfriends far from here and each month you say "oh love, I need money", you send this [message] to 10 [guys]. With 5 [responses] you pay the rent, without doing anything, it's a good life, right? So every night you come here to the club, when you want to earn even more, there are women who earn a lot of money...

It is interesting to perceive in this statement that Chris inverted his previous reasoning: here there are no longer "sexual tourists" attracted by the denunciations of "sexual crimes" by a "crazy city government" that provoked the changes in the Praia de Iracema. To the contrary, the women had assumed a morally

\footnotetext{
5 Cafuçu is a fundamental male category in sexual economies, used to designate partners considered to be of poor value in sex exchanges for money, although they may be seen as exotic in some contexts. A cafuçu man is marked by a lack of qualities and by the rudeness of manual labor. As a fluid category, it is used to mark differences of class and race between a woman and the cafuçu (França, 2013).
} 
condemnable behavior. They had become liars, greedy and uninterested in love: they tricked men who had fallen in love for financial gain, or, at least, the $5 \%$ of the men who responded for "good public", according to Chris' calculation. Both hypotheses, which are apparently antagonistic, emphasize changes in the morality of the subjects.

In 2016 the tourists "nearly disappeared" and competition among the women increased. More than once women would "come on to" a man already accompanied and ruin the possibility of an encounter for everyone. If he was a "good gringo" he became scared, if he was a "gringo-cafuçu" he would take advantage. In any case, the women lost.

Most of the "gringos" who went to the clubs today in Praia de Iracema live in Fortaleza and share the local dichotomic moralities. The similarity between the perspectives of these "gringos" with that which regulated the circulation of women in peripheral neighborhoods was such that it sustained the affirmation that these men "became cafuçus".

The "gringo-cafuçu" ruined his whiteness with "native" type behavior that reproduces local inequalities of gender and sexuality. These behaviors include "not wanting to pay", "being complicated" and being a "womanizer". They become equal to the "native men" in their gender relations, but remain white. The women hated the "gringos-cafuçus" mainly for their potential to trick them.

In the early years of the decade of 200o, the differences of gender, race, class and nationality in the context of Fortaleza generated in the "gringos" the perception of a generalized "need" that presupposed their economic generosity in affectionate relations with Brazilian women considered ideal partners because of their "simplicity" and disposition for sex. "Native" women, who articulate categories of race, class and age in different manners, situated the "gringos" as desirable romantic partners because they combined relations considered more egalitarian and a possibility for social ascension. This context sustained an "atmosphere of successful affairs and marriages" (Piscitelli, 2004, p. 301) which fed new love stories.

In the mid-2010s, "gringos" and "nativa" women who met in bars and clubs at the Praia de Iracema came to think negatively of each other, based on a different moral system. The Brazilian women believed that the "gringos" who went to these places were overbearing and dishonest in the intimate relations. The "gringos" felt "used" and "tricked" by the Brazilians who they met in that context.

"Gringos" and "nativa" women believe that there is no more love to be found at the Praia de Iracema. The women respond to this by embodying assertive femininities in their relations with the "gringos", by clarifying their "needs" and the rules of their work. The men react with skepticism and fraud to the contractual sexualeconomic exchange between equals that the women propose. The games of inferiority and superiority that sustained the morally valued encounters in this context were broken. So what motivated these people to continue to frequent the bars and clubs dedicated to transnational encounters?

Even if experience indicates that there was no more love at the Praia de Iracema, "gringos" and "nativa" women did not abandon the transnational romantic narrative between the pairing "príncipe"-"morena" [prince and brown-girl]. For these women, it is not a question of "dreams", as described by the policies to confront "sexual crimes", which portrayed them as "victims who sought their own abductors, blonds, with blue eyes" (Pretello e Dias, 1996, p. 9). Blanchette, Silva e Bento (2013) note that these mythic stories about "poor, innocent, uneducated mestiza girls", who sustained the confrontation of "sexual crimes" in Brazil, have little in common with the experiences of the sex workers.

The women who circulated at the Praia de Iracema in 2016 recognized the difficulties in finding love among the "gringos" who were at the bars and clubs. Men who "paid women" would be ruined for love. There was still, however, an imaginary about "other" Europeans who circulated among them: the "real gringos" with which they could experience a transnational story of love and consumption. The $5 \%$ calculated by Chris. 
The "gringos", in turn, continue to have fantasies of meeting a sensual "morena" on the tropical beaches who would care for them and seduce them without requiring anything in exchange. Many men consider that, in this case, they should offer some "help". However, to do so, this "morena" could not be "damaged" by involvement with sex work.

Moral purity was the element lacking in the bars and clubs of the Praia de Iracema. And being on the "right" side of morality did not depend only on the ethical conduct of the subjects. The production of the ethical subjectivities was informed by indications that often escaped control.

The narratives of romantic love that remained in the transnational sexual economies of Fortaleza in 2016 were missionary narratives. Through actions to confront "sexual crimes", young missionary couples that embody categories of gender, race, class and national differently, met, fell in love and got married. In this context, these couples materialized "true" love. The boys were imagined as good "gringos". The girls were submissive and sensual "morenas". The image that these couples consciously wanted to present was precisely this: the moralized transnational couple.

\section{Final considerations: eternal return}

If I favor the sea and everything that is of the sea, and even favor it most when it angrily contradicts me: (...) Oh how then could I not lust for eternity and for the nuptial ring of rings - the ring of recurrence! (Nietzsche, [1883]2008, p. 186)

The question of intentionality raised by Nietzsche resonates in many of the writings that seek new epistemologies to learn to live in ruins, and that inspired this article. Taking to the final consequences the idea of rationality as a starting point of science for progress, Nietzsche makes us face the absurdity of our work (Graeber, 2011). In search of an epistemology that is not distinguished from ontology, the feminist theoretical physicist Karen Barad proposes that it is necessary to think in entangled practices of agency, formed by complex networks of human and non-human agents and to analyze them through a methodology of diffraction, which considers differences.

Diffraction is also the name of the phenomenon that explains the gaps among the intentionalities and realities in the construction of the ports at Fortaleza (Ximenes Neto, Morais e Pinheiro, 2018). In classical physics, a phenomenon seen in waves is called diffraction. Thus, according to "laws of physics" the construction of a seawall affects the incidence of waves that come from the east, because the barrier changes their length and direction. Moreover, recognizing the web-like quality of the sea, we know that the waves carry sand, which, as matter, behaves differently in relation to the seawall, going beyond it, or accumulating around it.

The sea has its own agencies. The depositional patterns (of matter) and hydrodynamics (of waves) are also the routes by which matter and waves circulate, mutually remodeling them (Ximenes Neto, Morais e Pinheiro, 2018). The inequalities observed at the Praia de Iracema can be analyzed in an analogous manner.

Since the beach was feminized, in the early twentieth century, it has oscillated between being a territory-body essential to the alliance for progress and a territory-body for the contention of "mixture" and "degradation". While the local hierarchies of power remain unaltered, the racialized relationship of local exoticism with the "global market" was actively produced. However, when the generalized inferiority of the racialization made the limits of local class porous, these class limits were racialized to contain subaltern mobility. 
The image of the beach-woman-hooker confined in bodies and territories re-edited the slavocratic strategy of the "land of light" ${ }^{\text {in }}$ the late nineteenth century, in which the denial of existence of racial inequalities was triggered at the same time in which the racialization of class limited the mobility of poor people "of color".

Finally, in an ethnographic study at the Praia de Iracema, I concluded that, in the daily relations, the limits between agents of policies to confront "sexual crimes" and their public were porous. The indetermination of the borders would appear not only in the mechanisms of government, but also in the experiences of the subjects.

The skepticism that permeates the intimate relations established between "native" women and "gringos" who went to the bars and clubs of the Praia de Iracema were now supported in ideas of love mobilized in missionary projects to confront "sexual crimes".

Simultaneously, the missionary promise of love, enacted in the confrontation against "sexual crimes", would inadvertently reproduce the romantic ideas with which "native" women argued for their permanence in the circuit of bars and clubs in the Praia de Iracema in light of the drastic decrease of income from transnational sexual economies. With the end of international tourism in the neighborhood, sex workers and missionaries recreated narratives of transnational romance whose empiric anchor had shifted, but which did not fail to captivate us. Perhaps this is love.

The mutual implication between epistemology and ontology appears in each one of the themes debated in this article. It is important to recognize the entwined practices of agency between humans and non-humans because they produce the material worlds and ignoring them does not free us from responsibility for their effects (Barad, 2007). To return for the last time to the words of Zaratustra: "Never yet have I found the woman from whom I wanted children, unless it were this woman whom I love: for I love you, oh eternity!' (Nietzsche, [1883]2008, p. 184).

Submitted: January 25, 2020

Accepted: March 06, 2020

Translated by: Jeffrey Hoff

6 Ceara was called "the land of light" because it abolished slavery in 1884, 4 years before Brazil as a whole. 


\section{Bibliography}

ASSUNÇÃO, M. A. 2002. Escravidão em Fortaleza: um estudo a partir dos inventários post-mortem (1850-1884).

Dissertação apresentada ao Mestrado em História da Universidade Federal da Bahia, Salvador, BA.

BARAD, K. 2007. Meeting the universe halfway: quantum physics and the entaglement of matter and meaning. Durham and London: Duke University Press.

BARREIRA, I. A. F. 2007. "Usos da cidade: conflitos simbólicos em torno da memória e imagem de um bairro". Análise Social, 42(182): 163-180.

BENEVIDES, A. D. A. 2003. A estética do consumo no cenário social e cultural da Praia de Iracema. Tese de Doutorado apresentada ao Departamento de História do Instituto de Filosofia e Ciências Humanas da Universidade Estadual de Campinas, Campinas, SP.

BEZERRA, R. G. 2008. O bairro Praia de Iracema entre o "adeus" e a "boemia”. Usos, apropriações e representações de um espaço urbano.: Tese submetida à Coordenação do Programa de Pós-Graduação em Sociologia, Fortaleza, CE.

BLANCHETTE, T. G. 2011. "'Fariseus' e 'gringos bons': masculinidade e turismo sexual em Copacabana”. In: A. Piscitelli; G. Assis; J. M. N. Olivar (eds.), Gênero, sexo, afetos e dinheiro: mobilidades transnacionais envolvendo o Brasil. Campinas: UNICAMP/PAGU, 2011. pp. 57-102.

BLANCHETTE, T. G.; SILVA, A. P.; BENTO, A. R. 2013. "The Myth of Maria and the imagination of sexual trafficking in Brazil”. Dialectical Anthropology, 37(2): 195-227.

BLANCHETTE, T.; SILVA, A. P. D. 2012. "On bullshit and the trafficking of women: moral entrepreneurs and the invention of trafficking of persons in Brazil". Dialectical Anthropology, 36(1-2): 107-125.

COSTA, A. D. S. 2008. O tráfico de mulheres: o caso do tráfico interno de mulheres para fins de exploração sexual no estado do Ceará. Dissertação apresentada ao Programa de Pós-Graduação em Direito apresentado ao Centro de Ciências Jurídicas da Universidade de Fortaleza, Fortaleza, CE.

FEITOZA, J. M. B. D. A. C. 2010. Aspectos legais do tráfico interestadual de mulheres para fins de exploração sexual no estado do Ceará. Monografia apresentada ao curso de Pós-Graduação em Direito Penal e Direito Processual Penal da Universidade Estadual do Ceará, Fortaleza, CE.

FERREIRA SOBRINHO, J. H. 2011. Catirina, minha nêga, tão qurendo te vendê: escravidão, tráfico e negócios no Ceará do século XIX (1850-1881). Fortaleza: SECULT/CE.

FRANÇA, I. L. 2013. "Do universo perfeito ao cinemão: homossexualidade masculina, deslocamento e desejo na cidade de São Paulo". Revista de Ciências Sociais, 44(1): 44-73.

GRAEBER, D. 2011. Debt: the first 5,0oo years. Brooklyn: Melville House Publishing.

JUCÁ, G. N. M. 2003.Verso e reverso do perfil urbano de Fortaleza (1945-1960). São Paulo: Annablume.

LEAL, M. L.; LEAL, M. D. F. 2002. Pesquisa sobre Tráfico de Mulheres, Crianças e Adolescentes para fins de Exploração Sexual Comercial - PESTRAF. Relatório Nacional - Brasil. Brasília: CECRIA.

MAIA, L. et al. 1998. "The coastline of Fortaleza City. A product of environmental impacts caused by the Mucuripe harbor”. Arq. Ciên. Mar, 31(1-2): 93-100.

MANN, M. 2012. The hockey stick and the climate wars: dispatches from the front lines. New York: Columbia University Press.

MCCLINTOCK, A. 2010. Couro imperial: raça, gênero e sexualidade no embate colonial. Campinas: Editora da Unicamp.

MILLET, K. 197o. Política Sexual. Lisboa: Publicações Dom Quixote.

MORAIS, J. O. D. 1972. "Processos de assoreamento do Porto do Mucuripe". Arq. Ciên. Mar., 12(2): 139-149.

NIETZSCHE, F. 2008 [1883]. Thus spoke Zarathustra: a book for all and none. Cambridge:

Cambridge University Press. 
PISCITELLI, A. 1996. “'Sexo tropical': comentários sobre gênero e "raça” em alguns textos da mídia brasileira". Cadernos Pagu, 6/7: 10-33.

PISCITELLI, A. 2004. "Entre a Praia de Iracema e a União Européia: turismo sexual internacional e migração feminina”. In: A. Piscitelli; M. F. Gregori; S. Carrara (eds.), Sexualidade e saberes: convenções e fronteiras. Rio de Janeiro: Garamond. pp. 283-318.

PISCITELLI, A. 2004. "On 'Gringos' and 'Natives': gender and sexuality in the context of international sex tourism in Fortaleza". Vibrant, vol.1(1/2): 1-27.

PISCITELLI, A. 2005. "El tráfico del deseo: interseccionalidades no marco do turismo sexual no Nordeste do Brasil". Quaderns de L'Institut Catalé d'Antropologia, 2004(b): 1-15.

PISCITELLI, A. 2007. "Shifting Boundaries: Sex and Money in the North-East of Brazil". Sexualities, $10(4): 489-500$.

PISCITELLI, A. 2013. Trânsitos: brasileiras nos mercados transnacionais do sexo. Rio de Janeiro: EdUERJ.

PISCITELLI, A. Circuitos do desejo, economias sexuais e turismo internacional em Fortaleza. [S.l.]: [s.n.], no prelo.

PITOMBEIRA, E. D. S. 1976. "Deformação das ondas por difração no molhe do Porto do Mucuripe (Fortaleza Ceará - Brasil)". Arquivo de Ciências do Mar, 16(1): 55-58.

PRECIADO, P. B. 2008. Testo yonqui. Madrid: Espasa.

PRETELLO, C.; DIAS, S. 1996. Sexo turismo: o que a gente não faz para realizar um sonho? Olinda: Coletivo Mulher Vida.

RIOS, K. S. 2014. Isolamento e poder: Fortaleza e os campos de concentração na seca de 1932. Fortaleza: Imprensa Universitária.

RODRIGUES, N. S. 2013. O movimento dos peixes: do Acquário às ruas. Fortaleza: Monografia apresentada ao Curso de Ciências Sociais da Universidade Federal do Ceará.

ROUX, S. 2011. No money, no honey. Économies intimes du tourisme sexuel en Thailande. Paris:

La Découverte.

SOUSA, T. R. 2013. Tráfico de mulheres para fins de exploração sexual: a política de atendimento no Ceará. Fortaleza: Dissertação apresentada ao Curso de Mestrado Acadêmico em Serviço Social, Trabalho e Questão Social do Centro de Estudos Sociais Aplicados da Universidade Estadual do Ceará.

TSING, A. L. 2015. The mushroom at the end of the world: on the possibility of life in capitalist ruins. Princeton and Oxford: Princeton Univerisity Press.

XIMENES NETO, A.; MORAIS, J. O.; PINHEIRO, L. D. S. 2018. "Modificações na geomorfologia marinha a partir de estruturas porturárias: o caso do Mucuripe, Fortaleza - Ceará”. Geociências, 37(4): 793-805.

\author{
Ana Paula Luna Sales \\ Northeast Citizenship Institute, Brazil \\ https://orcid.org/00oo-0001-6532-1989 \\ Email:paulalunasales@gmail.com
}

